\title{
Possible role of imprinting in the Turner phenotype
}

\author{
C E Chu, M D C Donaldson, C J H Kelnar, P J Smail, S A Greene, W F Paterson, \\ J M Connor
}

In the present study we have examined a large number of liveborn Turner's syndrome patients to determine the parental origin of the retained normal $\mathrm{X}$ chromosome and to correlate this with the phenotype.

\section{Patients and methods}

Patients were seen in one of the four specialist growth clinics in Scotland or in the Medical Genetics Department in Glasgow. Samples were obtained from 63 patients and both parents, and genomic DNA was extracted from peripheral blood lymphocytes by standard methods.

DNA was subjected to double digest with $K p n \mathrm{I} / M s p \mathrm{I}$ and electrophoresis was carried out through $0.6 \%$ agarose gels for 48 hours to ensure maximum separation of bands. Southern blotting and ${ }^{32} \mathrm{P}$ labelling of probe $\mathrm{M} 27 \beta$, kindly provided by Dr I Craig, by the random primed method, hybridisation, and autoradiography were carried out according to standard procedure.

The karyotypes of the patients were as follows: $3245, \mathrm{X} ; 1045, \mathrm{X} / 46, \mathrm{Xi}(\mathrm{Xq}) ; 1045, \mathrm{X} /$ $46, \mathrm{Xr}(\mathrm{X})$; three $45, \mathrm{X} / 46, \mathrm{XX}$; and eight other karyotypes.

Pretreatment height of the child was plotted on Turner's syndrome centile charts ${ }^{8}$ and the parental heights plotted on normal female charts (after subtracting $12.5 \mathrm{~cm}$ from the paternal height to correct for sex difference).

Three phenotypic features were also analysed, heart anomalies (coarctation of aorta and bicuspid aortic valves), neck webbing, and renal abnormalities. Cardiac anomalies were diagnosed clinically with confirmation by echocardiograms. Renal anomalies were screened for using ultrasound and the 10 patients who did not have scans were not included in the analysis.

Correlation analysis was carried out using the MINITAB programme.

Health, Ninewells Hospital, Dundee, UK S A Greene

Correspondence to Dr Chu.

Received 5 May 1994 Revised version accepted for publication 6 July 1994

Table 1 Parental origin of the normal $X$ chromosome in patients with different karyotypes

\begin{tabular}{lccc}
\hline Karyotype & No & $\begin{array}{c}\text { Normal X maternal } \\
X^{M}(\%)\end{array}$ & $\begin{array}{l}\text { Normal X paternal } \\
X^{P}(\%)\end{array}$ \\
\hline 45,X & 32 & $23(72)$ & $9(28)$ \\
45,X/46,Xi(Xq) & 10 & $4(40)$ & $6(60)$ \\
45,X/46,Xr(x) & 10 & $7(70)$ & $3(30)$ \\
Other & 11 & $9(73)$ & $2(25)$ \\
Total & 63 & $43(68)$ & $20(32)$ \\
\hline
\end{tabular}

\section{Results}

Using this approach the parental origin of the normal $\mathrm{X}$ could be determined in every patient. Overall the normal $\mathrm{X}$ chromosome was maternal in $43(68 \%)$ and paternal in $20(32 \%)$ patients. Table 1 shows the parental origin with respect to karyotype. No unexpected $\mathrm{X}$ mosaicism was found in any patient.

Growth data were available for 36 patients and their parents of whom 24 retained the maternal $\mathrm{X}\left(\mathrm{X}^{\mathrm{M}}\right)$ and 12 the paternal $\left(\mathrm{X}^{\mathrm{P}}\right) \mathrm{X}$ chromosome. Correlations between maternal 
Table 2 Correlation of child's height with parental height and mid-parental height (MPH) in Turner's syndrome

\begin{tabular}{llll}
\hline $\begin{array}{l}\text { Origin of } \\
X\end{array}$ & $\begin{array}{l}\text { Correlation with } \\
\text { maternal ht }\end{array}$ & $\begin{array}{l}\text { Correlation with } \\
\text { paternal ht }\end{array}$ & $\begin{array}{l}\text { Correlation with } \\
M P H\end{array}$ \\
\hline $\mathrm{X}^{\mathrm{M}}$ & $\mathrm{r}=0.607$ & $\mathrm{r}=0.117$ & $\mathrm{r}=0.52$ \\
& $(\mathrm{p}<0.01)$ & $(\mathrm{p}>0.05)$ & $(\mathrm{p}<0.01)$ \\
$\mathrm{X}^{\mathrm{P}}$ & $\mathrm{r}=-0.259$ & $\mathrm{r}=0.225$ & $\mathrm{r}=-0.02$ \\
& $(\mathrm{p}>0.05)$ & $(\mathrm{p}>0.05)$ & $(\mathrm{p}>0.05)$ \\
\hline
\end{tabular}

height centile, paternal height centile, and midparental height centile were determined for the $\mathrm{X}^{\mathrm{M}}$ and $\mathrm{X}^{\mathrm{P}}$ groups and are shown in table 2. There was a highly significant correlation between child height centile and maternal height centile for $\mathrm{X}^{\mathrm{M}}$ but not for $\mathrm{X}^{\mathrm{P}}$. The correlation between child height centile and paternal height centile was not significant for $\mathrm{X}^{\mathrm{M}}$ or $\mathrm{X}^{\mathrm{P}}$. Child and mid-parental height centile correlated significantly for $\mathrm{X}^{\mathrm{M}}$ but this was a less significant correlation than that for maternal height centile. There was no significant correlation between mid-parental and child height centile for $\mathrm{X}^{\mathrm{P}}$.

In this cohort 10 patients had cardiac anomalies (coarctation or bicuspid aortic valves or both) diagnosed clinically, of whom nine were $\mathrm{X}^{\mathrm{M}}$ and one $\mathrm{X}^{\mathrm{P}}$. Neck webbing was present in seven patients all of whom were $X^{\mathrm{M}}$. Eight patients had abnormal kidneys (three horseshoe, two duplex, and three dysplastic); six were $\mathrm{X}^{\mathrm{M}}$ and two were $\mathrm{X}^{\mathrm{P}}$. The 10 patients who had not had renal imaging were excluded from the analysis. There was no statistical difference between the $\mathrm{X}^{\mathrm{M}}$ and $\mathrm{X}^{\mathrm{P}}$ groups using Fisher's exact probability test, but since the numbers were small analysis was carried out after pooling data from other studies..$^{3-5}$ Using this method and applying the $\chi^{2}$ test with Yates's correction (table 3 ), there was a highly significant difference between $\mathrm{X}^{\mathrm{M}}$ and $\mathrm{X}^{\mathrm{P}}$ for cardiovascular anomalies $(0.01>p>0.001)$, a less significant difference for neck webbing $(p<0.05)$, and no significant difference for renal anomalies $(p>0.05)$.

\section{Discussion}

We have shown in this study that the pretreatment height of girls with Turner's syndrome correlates more strongly with maternal than paternal height for children retaining the normal maternal $\mathrm{X}$ chromosome. The results for those children retaining the paternal $X$ show poor correlation with either maternal or paternal height centiles, although this may be because of the small numbers of $\mathrm{X}^{\mathrm{P}}$ patients. These results are consistent with the observation by Salerno et al that the final height in 67 Turner's syndrome patients showed a strong correlation between patient's height and maternal height $(r=0 \cdot 607)$. They suspected that this was because of the bias for retention of the maternal $\mathrm{X}$ but did not perform studies of origin of the normal $\mathrm{X}$ on their patients. We have chosen to compare pretreatment height centiles of patients and parents using corrected paternal heights so that younger patients could be included in the analysis. Lyon et al have shown that Turner's syndrome patients remain on the same centile line if untreated and projecting final height using these charts is generally accepted. These results may have clinical implications for better counselling of newly diagnosed patients as to height prognosis.

The present findings also indicate that imprinting may play a part in both cardiovascular anomalies and neck webbing but not renal anomalies. This would be consistent with the proposed mechanism for formation of both neck webbing and cardiac abnormalities owing to abnormal development of the lymphatic system. Clark ${ }^{9}$ found in the chick that disordered lymphatic drainage leads to distension of the cardiac lymphatics which may encroach on the ascending aorta and alter intracardiac blood flow and lead to structural abnormalities of the aorta and aortic valves. Abnormality of lymphatic drainage may also lead to cystic hygroma and neck webbing in the child. However, the mechanism for renal abnormalities is likely to be different resulting from abnormalities in ureteric or metanephric budding or vascular dysplasia. ${ }^{10}$

Imprinting of areas of the $\mathrm{X}$ chromosome has been postulated in the mouse where $\mathrm{XO}$ mice retaining the paternal $X$ are developmentally retarded and smaller than their $\mathrm{XX}$ sibs, whereas XO mice retaining the maternal $\mathrm{X}$ are significantly larger than their XX sibs. ${ }^{11}$ Also of interest is the fact that mouse androgenetic cell lines contribute more to the mesodermal derivatives, such as muscle, skeleton, kidney, heart, and dermis, but less to the ectodermal derivatives, such as brain. ${ }^{12}$

This study has shown that some aspects of the Turner's syndrome phenotype may be influenced by imprinting of some areas of the $\mathrm{X}$ chromosome. However, cryptic X mosaicism and anomalous $\mathrm{X}$ inactivation of structurally abnormal $\mathrm{X}$ chromosomes may be complicating factors in some patients. Although no evidence was found for unexpected $\mathrm{X}$ mosaicism in the present study in blood, this factor may modify the phenotype in those patients who do not appear to fit this imprinting model. Further studies of larger numbers of patients analysing multiple tissues for both $\mathrm{X}$ mosaicism and $X$ inactivation patterns may clarify the relationship of imprinting, $\mathrm{X}$ inactivation, and cryptic mosaicism.

Table 3 Pooled data from four studies of various phenotypic features in Turner's syndrome

\begin{tabular}{|c|c|c|c|c|c|c|}
\hline \multirow[t]{2}{*}{ Study } & \multicolumn{2}{|c|}{ Cardiac anomalies } & \multicolumn{2}{|l|}{ Neck webbing } & \multicolumn{2}{|c|}{ Renal anomalies } \\
\hline & $\begin{array}{l}\text { Affected/total } \\
X^{M}\end{array}$ & ${ }_{X^{\boldsymbol{\beta}}}^{\text {Affected/total }}$ & $\begin{array}{l}\text { Affected/total } \\
X^{M}\end{array}$ & ${ }_{X^{P}}^{\text {Affected/total }}$ & $\underset{X^{M}}{\text { Affected/total }}$ & ${ }_{X^{\rho}}^{\text {Affected/total }}$ \\
\hline $\begin{array}{l}\text { Ross } e t a l^{5} \\
\text { Mathur } e t a l^{4} \\
\text { Lorda-Sanchez et } a l^{3} \\
\text { Present study } \\
\text { Total }\end{array}$ & $\begin{array}{r}11 / 17 \\
7 / 18 \\
7 / 12 \\
9 / 43 \\
34 / 90\end{array}$ & $\begin{array}{l}0 / 7 \\
3 / 7 \\
0 / 4 \\
1 / 20 \\
4 / 38\end{array}$ & $\begin{array}{r}12 / 17 \\
3 / 18 \\
11 / 20 \\
7 / 43 \\
33 / 98\end{array}$ & $\begin{array}{l}3 / 7 \\
0 / 7 \\
3 / 5 \\
0 / 20 \\
6 / 39\end{array}$ & $\begin{array}{r}3 / 17 \\
3 / 18 \\
10 / 19 \\
6 / 38 \\
22 / 92\end{array}$ & $\begin{array}{l}1 / 7 \\
0 / 7 \\
2 / 2 \\
2 / 15 \\
5 / 31\end{array}$ \\
\hline
\end{tabular}


The authors would like to thank Dr I Craig for the gift of probe M27 $\beta$, and specialist growth nurses $E$ Whyte, $H$ Watson, and $G$ Lamont. This work was funded by grants from Kabi Pharmacia and SHERT.

1 Jacobs PA, Betts PR, Cockwell AE, et al. A cytogenetic and molecular reappraisal of a series of patients with Turner's molecular reappraisal of a series of patients with
syndrome. Ann Hum Genet 1990;54:209-23.

2 Hassold T, Benham F, Leppert M. Cytogenetic and molecular analysis of sex-chromosome monosomy. Am $\mathcal{~ H u m}$ Genet 1988;42:534-41.

3 Lorda-Sanchez I, Binkert F, Maechler M, Schinzel A. Molecular study of $45, \mathrm{X}$ conceptuses; correlation with clinical findings. Am $\mathcal{F}$ Med Genet 1992;42:487-90.

4 Mathur A, Stekol L, Schatz D, MacLaren NK, Scott ML, Lippe B. The parental origin of the single X chromosome in Turner's syndrome: lack of correlation with parental age or clinical phenotype. Am f Hum Genet 1991;48:

5 Ross JL, Hall JG, Pfender EG. The contribution of im- printing of the phenotype in Turner syndrome. Am $\mathcal{f ~ H u m}$ Genet 1991;49:19A.

6 Brook CGD, Murset G, Zachmann M, Prader A. Growth in children with 45,XO Turner's syndrome. Arch Dis Child 1974;49:789-95.

7 Salerno MC, Job JC. La taille dans le syndrome de Turner. Correlations avec la taille des parents. Arch Fr Pediat 1987;44:863-5.

8 Lyon AJ, Preece MA, Grant DB. Growth curve for girl with Turner syndrome. Arch Dis Child 1985;60:932-5. 9 Clark EB. Neck web and congenital heart defects: a paratology 1984;29:355-61.

10 Lippe BM. Physical and anatomical abnormalities in Turner syndrome. In: Rosenfeld RG, Grumbach MM, eds. Turner syndrome. New York: Marcel Dekker, 1990:183-96.

11 Thornhill AR, Burgoyne PS. A paternally imprinted X chromosome retards the development of the early mouse embryo. Development 1993;118:171-4.

12 Surani MA, Kothary R, Allen ND, et al. Genome imprinting and development in the mouse. Development Suppl 1990; 110:89-98. 